\title{
Sanksi Administrasi Terhadap Kebakaran Hutan Dan Lahan Oleh Badan Hukum Perdata Di Kabupaten Muaro Jambi
}

\author{
Fitria, Syamsir \\ Fakultas Hukum, Universitas Jambi, Indonesia
}

\begin{abstract}
ABSTRAK
Di dalam Undang-Undang Kehutanan telah diatur tentang adanya larangan untuk membakar hutan dan lahan seperti yang terdapat dalam Pasal 50 ayat (3) huruf d yang menyatakan bahwa "setiap orang dilarang membakar hutan", Pasal 69 ayat (1) huruf a dan h UU-PPLH menyatakan, Setiap orang dilarang: "melakukan perbuatan yang mengakibatkan pencemaran dan/atau perusakan lingkungan hidup; dan melakukan pembukaan lahan dengan cara membakar. Dari Penelitian ini di harapkan pelanggaran yang dilakukan pemegang izin usaha dibidang Perkebunan yang telah melakukan pembakaran hutan dan lahan di Kabupaten Muaro Jambi patut dikenakan sanksi administrasi yang tegas. Sanksi administrasi merupakan salah satu instrumen hukum dalam menjaga kelestarian lingkungan dan bersifat pemulihan atau Repartoir. Tetapi dalam pelaksanaannya sering kali kita melihat sulitnya menerapkan sanksi administrasi terhadap pelanggaran-pelanggaran yang dilakukan oleh pemegang izin Perkebunan karena masalah pembuktian terhadap pelanggaran yang dilakukan oleh pemegang izin usaha. Apabila penerapan sanksi administrasi tidak diterapkan, maka kerusakan terhadap lingkungan akan semakin meluas dan masalah pembakaran lahan tidak akan kunjung selesai. Oleh sebab itu, pemerintah Kabupaten Muaro Jambi sangat di tuntut untuk menyelesaikan kasus-kasus pembakaran hutan dan lahan secara serius dan menerapkan sanksi administrasi sesuai dengan peraturan perundang-undangan yang berlaku.
\end{abstract}

Kata Kunci: Sanksi administrasi, kebakaran hutan dan lahan, badan hukum perdata

\section{PENDAHULUAN}

\section{Latar Belakang Masalah}

Lingkungan merupakan hal yang sangat esensial dan melengkapi kehidupan manusia. Manusia dan lingkungan meniscayakan adanya hubungan timbal balik yang harmonis karena saling mempengaruhi satu dengan lainnya demi menciptakan lingkungan hidup yang seimbang, stabil, dan produktif. Pasal 33 ayat (3) menegaskan bahwa bumi dan air beserta seluruh kekayaan alam yang terdapat di dalamnya dikuasai oleh negara dan dipergunakan sepenuhnya demi kepentingan rakyat. ${ }^{1}$ Untuk dapat melaksanakan amanat tersebut, dibentuk peraturan dalam bentuk Undang-Undang, Peraturan Pemerintah, Peraturan Presiden, hingga dengan Peraturan Daerah. Tujuan dari dibentuknya produk perundang-undangan tersebut

\footnotetext{
${ }^{1}$ Periksa pasal 33 ayat (3) Undang-Undang Dasar 1945.
} 
adalah untuk menjaga kelestarian sumber daya alam terhadap pengelolaan lingkungan hidup.

Dalam Undang-Undang Nomor 41 Tahun 1999 dinyatakan bahwa penyelenggaraan kehutanan itu ditujukan untuk sebesar-besar kemakmuran rakyat secara adil dan berkelanjutan. Adapun dalam Undang-Undang Nomor 32 Tahun 2009 dikatakan bahwa tujuan Perlindungan dan Pengelolaan Lingkungan Hidup adalah untuk melindungi wilayah Negara Kesatuan Republik Indonesia dari pencemaran dan/atau kerusakan lingkungan hidup.

Undang-Undang tetnang Kehutanan telah mengatur adanya larangan orang atau badan hukum perdata dalam membakar hutan dan lahan sebagaimana tercantum pada Pasal 50 ayat (3) huruf d yang menyatakan "setiap orang dilarang membakar hutan." Demikian pula Pasal 69 ayat (1) huruf a dan h UU-PPLH yang menyatakan,"setiap orang dilarang melakukan perbuatan yang mengakibatkan pencemaran dan/atau perusakan lingkungan hidup, dan melakukan pembukaan lahan dengan cara membakar."

Pada Pasal 88 Undang-Undang Nomor 32 Tahun 2009 Tentang Perlindungan dan Pengelolaan Lingkungan Hidup dijelaskan bahwa "setiap orang yang tindakannya, usahanya, dan/atau kegiatannya menggunakan B3, menghasilkan dan/atau mengelola limbah B3, dan/atau yang menimbulkan ancaman serius terhadap kehidupan manusia".

Berbagai kegiatan manusia dapat terhadap lingkungan dapat menimbulkan akibat serius seperti pencemaran. Menurut Inosentius Samsul, pencemaran terdiri dari berbagai macam bentuk, yaitu: pertama, pencemaran kronis, yaitu pencemaran yang mengakibatkan kerusakan dan pencemaran secara progresif meskipun lambat; kedua, pencemaran kejutan, yaitu pencemaran yang mengakibatkan kerusakan yang sifatnya mendadak tapi berat. Pencemaran jenis ini umumnya muncul dari kecelakaan; ketiga, pencemaran berbahaya, yang biasanya mengakibatkan kerugian biologis yang berat serta adanya radioaktivitas yang menyebabkan terjadinya kerusakan genetis; dan keempat, pencemaran katastrofis, yaitu pencemaran yang dapat mengakibatkan kematian organisme hidup yang banyak, bahkan kepunahan. ${ }^{2}$

Pada setiap peristiwa kebakaran yang mengakibatkan kerusakan lingkungan yang dilakukaftn oleh badan hukum perdata, maka badan tersebut seharusnya bertanggung jawab atas perbuatan yang mengakibatkan pencemaran lingkungan tersebut. Sekalipun perbuatan yang mengakibatkan kebakaran hutan tersebut dilakukan secara tanpa disengaja / alpa, pelaku pembakaran tersebut dapat dikenakan sanksi terutama dengan sanksi administrasi sebagai sanksi reparatoir.

Dampak yang terlihat dari kebakaran hutan dan lahan yang dilakukan oleh orang atau badan hukum perdata sebagai berikut. "Pertama, banyak timbulnya penyakit infeksi saluran pernafasan akut bagi masyarakat akibat pencemaran asap.

${ }^{2}$ Ibid 
Kedua, secara sosial dan ekonomi masyarakat sangat dirugikan karena berkurangnya efesiensi kerja baik di kantor-kantor dan di sekolah-sekolah karena diliburkan serta transportasi penghubung banyak terganggu. Ketiga, kerugian imateriil dan materiil pada masyarakat setempat bahkan menyebabkan transboundary haze pollution (pencemaran asap lintas batas) ke wilayah negara-negara tetangga, seperti Singapura, Brunei, dan Malaysia."3

Seperti yang kita ketahui pemerintah daerah dalam mengatasi masalah dan persoalan kebakaran dan lahan mengalami banyak kesulitan dalam hal ini untuk mengatasi masalah tersebut karena tidak bisa dipungkiri pemerintah daerah memiliki kurang sarana dan prasarana yang lengkap dan memadai untuk memadamkan api bahkan hanya mempunyai peralatan yang seadanya, sedangkan kawasan lahan perkebunan yang terbakar sangat luas dan membutuhkan peralatan yang maksimal sehingga memungkinkan api cepat dapat dipadamkan dan dapat mengurangi polusi udara.

Dalam mencegah masalah terjadinya pembakaran hutan dan lahan adalah melalui penegakan hukum atau penerapan sanksi administrasi yang tegas. Mengutip JBJM Ten Berge, sebagaimana dilansir Philipus M. Hadjon menyebutkan bahwa "dalam hal penerapan Instrumen penegakan hukum administrasi adalah melalui pengawasan dan penegakan sanksi. Pengawasan merupakan langkah preventif untuk memaksakan kepatuhan, sedangkan penerapan sanksi merupakan langkah represif untuk memaksakan kepatuhan".

Adanya Undang-Undang Nomor 23 tahun 2014 terlah memperlihatkan kurangnya perlindungan dan pengelolaan di wilayah kabupaten/kota. Di satu sisi, urusan perlindungan terhadap kerusakan hutan diserahkan kepada pemerintah daerah provinsi selaku pemegang urusan kehutanan di daerah. Padahal di sis lain, kegiatan perlindungan hutan ini tidak hanya mencakup kawasan konservasi saja, melainkan juga mencakup kawasan hutan lindung, kawasan hutan produksi dan kawasan hutan lainnya.

Berdasarkan Pasal 33 ayat (3) Undang-Undang 1945 amandemen ke-4 menyatakan bahwa: "Bumi dan air dan kekayaan alam yang terkandung didalamnya dikuasai oleh Negara dan dipergunkan untuk sebesar-besarnya kemakmuran rakyat." Pada sila ke-5 dari Pancasila disebutkan bahwa "Kesejahteraan sosial bagi seluruh rakyat Indonesia. Dalam Pasal 28H UndangUndang Dasar Tahun 1945 menyatakan: "Setiap orang berhak hidup sejahtera lahir dan batin, bertempat tinggal dan mendapatkan lingkungan hidup yang baik dan sehat serta berhak memperoleh pelayanan kesehatan." Oleh karena itu, Pemerintah Pusat dan Pemerintah Daerah harus memperhatikan dalam pengelolaan dan perlindungan Lingkungan hidup untuk melaksanaan pembangunan berkelanjutan yang bertujuan untuk menjadikan lingkungan hidup Indonesia menurut apa yang

\footnotetext{
${ }^{3}$ Inosentius Samsul, Loc. Cit.
} 
telah diamanatkan oleh Undang-Undang Pengelolaan Lingkungan Hidup, yaitu agar fungsi lingkungan hidup tetap lestari dan agar pencemaran dan kerusakan di dalamnya tidak terjadi.

Berdasarkan data yang penulis dapatkan dari penelitian terdahulu penulis pada tahun 2017 mengenai estimasi dampak kebakaran hutan dan lahan di Kabupaten Muaro Jambi yang dilakukan oleh badan hukum perdata dapat dilihat dari tabel berikut:

\begin{tabular}{clcc}
\hline No & \multicolumn{1}{c}{ Lokasi Kebakaran } & $\begin{array}{c}\text { Luas Kebakaran }( \pm \mathrm{Ha}) \text { yang } \\
\text { teridikasi }\end{array}$ & $\begin{array}{c}\text { Estimasi terjadinya kerugian } \\
\text { terhadap dampak Kebakaran (Rp) }\end{array}$ \\
\hline 1 & PT. Puri Hijau Lestari & $70 \mathrm{Ha}$ & 2.456 .160 .000 \\
2 & PT. Citra Quinta & $30 \mathrm{Ha}$ & 1.052 .640 .000 \\
3 & PT. Bahari Gembira Ria & $25 \mathrm{Ha}$ & 877.200 .000 \\
4 & PT. Ricky Mas Jaya & $35 \mathrm{Ha}$ & 1.219 .050 .000 \\
5 & PT. Bara Eka Prima & $300 \mathrm{Ha}$ & 10.449 .000 .000 \\
6 & PT. Bukit Sawit Sejahtera & $60 \mathrm{Ha}$ & 2.089 .800 .000 \\
7 & PT. Ricky Kurniawan & $175 \mathrm{Ha}$ & 6.140 .400 .000 \\
& Kertapers & & 1.393 .200 .000 \\
8 & PT. Bumi Andalas & $40 \mathrm{Ha}$ & 1.741 .500 .000 \\
9 & PT. Agung Perkasa Sawit & $50 \mathrm{Ha}$ & 1.578 .960 .000 \\
10 & PT. Brahma Bhina Bakti & $45 \mathrm{Ha}$ & 1.052 .640 .000 \\
11 & PT. Petaling Mandraguna & $30 \mathrm{Ha}$ & 1.052 .640 .000 \\
12 & PT. Makmur Bina Bestari & $30 \mathrm{Ha}$ & 1.052 .640 .000 \\
13 & PT. Era Sakti W. & $30 \mathrm{Ha}$ & 105.264 .000 \\
14 & PT. BAM & $3 \mathrm{Ha}$ & 6.912 .336 .000 \\
15 & PT. Jambi Batanghari & $130 \mathrm{Ha}$ & 7.017 .600 .000 \\
& Plantion & & 1.754 .400 .000 \\
16 & PT. Mas Plantion & $90 \mathrm{Ha}$ & 47.945 .430 .000 \\
& & $50 \mathrm{Ha}$ & \\
17 & PT. Wana Seponjen & $1.113 \mathrm{Ha}$ & \\
\hline & $\quad$ Jumlah & &
\end{tabular}

Dari data tersebut terlihat lahan gambut yang ada di Indonesia diperkirakan berjumlah 20,6 juta ha (10,8\%) dari luas seluruh daratan di Indonesia, dari 7,2 juta ha (35\%) terdapat di Wilayah Sumatera. Sedangakan Luas lahan gambut yang ada di wilayah Provinsi Jambi berjumlah 4.043 .602 ha (45 \% dari luas lahan keseluruhan). Dalam hal ini total Penggunaan seluruh daerah lahan gambut untuk kepentingan perkebunan yang berada di Wiklayah Provinsi Jambi diperkirakan 817.593 ha (Dinas Perkebunan Provinsi Jambi, 2016).

Sektor perkebunan adalah bagian sangat penting dalam mendukung arah pembangunan di Wilayah Provinsi Jambi. Berdasarkan data dari Rencana Tata Ruang Wilayah Provinsi (RTRWP) Provinsi Jambi dan yang diatur di Peraturan Daerah (PERDA) No.10 Tahun1994 yang menyatakan bahwa potensi areal perkebunan di Wilayah Provinsi Jambi terdapat seluas 3.300.7 67,5 ha. 


\section{Rumusan Masalah}

1. Bagaimanakah bentuk sanksi administrasi terhadap yang melakukan pembakaran hutan dan lahan di Kabupaten Muaro Jambi ?

2. Bagaimanakah Bentuk Pertanggungjawaban terhadap Pembakaran Hutan dan Lahan di Kabupaten Muaro Jambi ?

\section{TINJAUAN PUSTAKA}

\section{Penegakan Hukum Administrasi Negara}

Menurut Ten Berge, dikutip Ridwan H.R., menyebutkan bahwa "instrumen penegakan Hukum Administrasi Negara meliputi dari unsure pengawasan dan penegakan sanksi administrasi. Pengawasan merupakan langkah preventif untuk memaksakan kepatuhan, sedangkan penerapan sanksi merupakan langkah represif untuk memaksakan kepatuhan."4 Pengawasan dilakukan terhadap tindakan pemerintah dimaksudkan agar pemerintah dalam menjalankan aktivitasnya sesuai dengan aturan hukum. Pengawasan juga merupakan upaya preventif yang tujuannya adalah untuk merestorasi suatu keadaan sebelum terjadinya suatu pelanggaran terhadap aturan atau norma-norma hukum. Namun, yang terpenting adalah bahwa pengawasan dilakukan demi upaya memberikan perlindungan hukum untuk rakyat. ${ }^{5}$

Ten Berge memberikan penjelasan bahwa "sanksi merupakan inti dari penegakan Hukum Administrasi Negara. Sanksi biasanya diletakkan pada bagian akhir setiap peraturan dan sanksi diperlukan untuk menjamin penegakan Hukum Administrasi Negara."6 Lalu menurut Philipus M. Hadjon bahwa, "memasukkan kewajiban-kewajiban dan larangan-larangan bagi para warga di dalam peraturan perundang-undangan tata usaha negara adalah tidak berguna. Karena menurutnya aturan-aturan yang diberlakukan kepada para warga ini tidak dapat dipaksakan oleh Tata Usaha Negara."7 Dalam hal ini penerapan sanksi sangat penti ng dalam menerapkan norma atau hukum karena tanpa memasukan sanksi maka hukum tersebut tidak akan bias diterapkan.

\section{Bentuk sanksi administrasi terhadap yang melakukan pembakaran hutan dan lahan diKabupaten Muaro Jambi}

Pembakaran hutan dan lahan merupakan perbuatan yang dilarang karena selain melanggar Pasal 50 ayat 3 huruf (d) Undang-Undang Nomor 41 Tahun 1999 jo Undang-Undang Nomor 19 Tahun 2004 tentang Kehutanan, Pasal 69 ayat 1 huruf d Undang-Undang Nomor 32 Tahun 2009 tentang Perlindungan dan Pengelolaan

\footnotetext{
${ }^{4}$ Ridwan H.R., Op. Cit., halaman 296.

${ }^{5}$ Ibid, halaman 297.

${ }^{6}$ Ibid, halaman 298.

${ }^{7}$ Ibid, halaman 298.
} 
Lingkungan Hidup, Pasal 56 ayat 1 Undang-Undang Nomor 39 Tahun 2014 tentang Perkebunan juga melanggar Pasal 11 Peraturan Pemerintah Nomor 4 Tahun 2001 Tentang Pengendalian Kerusakan dan atau Pencemaran Lingkungan Hidup Yang Berkaitan Dengan Kebakaran Hutan dan atau Lahan.

Dampak kebakaran hutan dan lahan yang demikian besar mengakibatkan lahirnya pengaturan terhadap larangan untuk membakar hutan dan lahan kepada setiap orang yang melakukan usaha khususnya di bidang perkebunan, ketentuan tersebut tercantum di dalam Pasal 69 ayat (1) huruf h Undang-Undang Nomor 32 Tahun 2009 tentang Perlindungan dan Pengelolaan Lingkungan Hidup dan Pasal 56 ayat (1) Undang-Undang Nomor 39 Tahun 2014 tentang Perkebunan. ${ }^{8}$ Upaya utama yang harus dilakukan untuk menyikapi kerusakan lingkungan hidup dalam sistem pengelolaan lingkungan hidup yang berkelanjutan, maka diperlukan tindakan preventif berupa perizinan dalam bentuk izin lingkungan dan izin usaha yang berkaitan dengan ekspoitasi sumber daya alam. Instrumen pencegahan dalam perizinan bidang perkebunan terdapat di dalam Pasal 67 Undang-Undang Nomor 39 Tahun 2014 tentang Perkebunan, menyebutkan:

1. Setiap Pelaku Usaha Perkebunan wajib memelihara kelestarian fungsi lingkungan hidup.

2. Kewajiban memelihara kelestarian fungsi lingkungan hidup sebagaimana dimaksud pada ayat (1) dilakukan sesuai dengan ketentuan peraturan perundangan-undangan.

3. Untuk memelihara kelestarian fungsi lingkungan hidup sebagaimana dimaksud ayat (1), sebelum memperoleh Izin Usaha Perkebunan, Perusahaan Perkebunan harus:

1) Membuat analisis mengenai dampak lingkungan hidup atau upaya pengelolaan lingkungan hidup dan upaya pemantauan lingkungan hidup ;

2) Memiliki analisis dan manajemen risiko bagi yang menggunakan hasil rekayasa genetik; dan

3) Membuat pernyataan kesanggupan untuk menyediakan sarana, prasarana, dan sistem tanggap darurat yang memadai untuk menanggulangi terjadinya kebakaran.

Kewenangan untuk menerbitkan izin usaha perkebunan sebagaimana diatur dalam Pasal 48 ayat (1) dan ayat (2) Undang-Undang Nomor 39 Tahun 2014 tentang Perkebunan. ${ }^{9}$ Salah satu prinsip di dalam Hukum Administrasi Negara adalah bahwa pejabat yang berwenang mengeluarkan izin memeliki kewajiban untuk melakukan pengawasan terhadap izin usaha tersebut, sebagaimana telah diatur dalam Pasal 72 Undang-Undang Nomor 32 Tahun 2009 tentang Perlindungan dan

${ }^{8}$ Periksa Pasal 69 ayat (1) huruf h Undang-Undang Nomor 32 Tahun 2009 tentang Perlindungan dan Pengelolaan Lingkungan Hidup dan Pasal 56 ayat (1) Undang-Undang Nomor 39 Tahun 2014 tentang Perkebunan.

${ }^{9}$ Periksa Pasal 48 ayat (1) dan ayat (2) Undang-Undang Nomor 39 Tahun 2014 tentang Perkebunan. 
Pengelolaan Lingkungan Hidup. ${ }^{10}$ Pengawasan bertujuan untuk mencapai ketaatan masyarakan terhadap norma hukum dan juga dapat mengidentifikasikan terjadinya pelanggran sejak dini.

Wilayah Provinsi Jambi yang mengalami kebakaran hutan dan lahan yang cukup parah yaitu di daerah Kabupaten Muaro Jambi, sebab sebagian besar kebakaran hutan dan lahan di wilayah tersebut berada di kawasan hutan dan lahan gambut. Kebakaran hutan dan lahan gambut di Muaro Jambi terjadi sejak AgustusOktober 2019 diperkirakan sudah mencapai \pm 40.351 hektare. Kebakaran hutan dan lahan gambut tersebut terjadi di areal HPH dan juga perusahaan perkebunan kelapa sawit.

Daftar luas lahan perusahaan perkebunan kelapa sawit yang terbakar, sebagai berikut:

1. PT. PUTRA DUTA INDAH WOOD, Lebih Kurang 16.327 ha terbakar.lokasi desa muaro kumpeh, kecamatan kumpe kumpeh.

2. PT MEGA ANUGRAH SAWIT luas lahan terbakar 1.500 hektare, lokasi di Desa Sipin Teluk Duren, Kecamatan Kumpeh Ulu.

3. PT RICKY KURNIAWAN KERTAPERSADA luas lahan 1.200 hektare, lokasi di Desa Puding, Kecamatan Kumpeh Ilir.

4. PT. BARA EKA PRIMA luas lahan 2.005 hektare, lokasi di Desa Puding, Kecamatan Kumpeh Ilir.

5. PT. SAWIT MAS PLANTATION luas lahan 800 hektare, lokasi di Desa Puding, Kecamatan Kumpeh.

6. PT. BUKIT BINTANG SAWIT luas lahan 8 hektare, lokasi di Kemingking Dalam, Kecamatan Maro Sebo.

7. PT. RIKCKY KURNIAWAN KERTAPERSADA, Luas area terbakar mencapai $\pm \mathbf{1 . 2 0 0}$ ha, lokasi desa mekar sari kecamatan kumpeh.

8. PT. WANA SEPONJEN INDAH luas lahan 32 hektare, lokasi Desa Sungai Bungur, Kecamatan Kumpeh.

9. PT. PURI HIJAU LESTARI luas lahan 53 hektare, lokasi di Desa Sungai Bungur, Kecamatan Kumpeh. ${ }^{11}$

kebakaran banyak terjadi di dalam areal perusahaan yang tidak mampu melindungi dan mengelola lahan gambut, serta tidak memiliki perlengkapan sarana dan prasarana pengendalian kebakaran. Kondisi ini memerlukan tindakan pemerintah terutama mengenai penegakan hukum berupa sanksi administrasi atas izin lingkungan yang dikeluarkan oleh pemerintah terhadap perusahaan yang mengakibatkan kebakaran pada areal konsesinya. Hidup.

${ }^{10}$ Pasal 72 Undang-Undang Nomor 32 Tahun 2009 tentang Perlindungan dan Pengelolaan Lingkungan

${ }^{11}$ Bidang Penataan Lingkungan Hidup Dinas Lingkungan Hidup Provinsi Jambi. 
Penerapan sanksi administrasi sebagaimana diatur dalam pasal diatas merupakan kewenangan yang dimiliki oleh pejabat administrasi, dalam hal ini Menteri selaku pejabat Pemerintah Pusat. Disamping itu pejabat daerah (Gubernur dan Bupati/walikota) juga dapat menjatuhkan sanksi administrasi sesuai kewenangannya. Bahkan apabila kewenangan pejabat daerah tidak digunakan, maka penerapan sanksi administrasi tersebut dapat dilaksnakan oleh Menteri selaku Pemerintah Pusat. Hal ini diatur dalam Pasal 77 Undang-Undang Nomor 32 Tahun 2009 tentang Perlindungan dan Pengelolaan Lingkungan Hidup.

Dari data Dinas Lingkungan Hidup Provinsi jambi dapat dilihat Kumulatif Hot Spot Di wiliyah Provinsi Jambi:

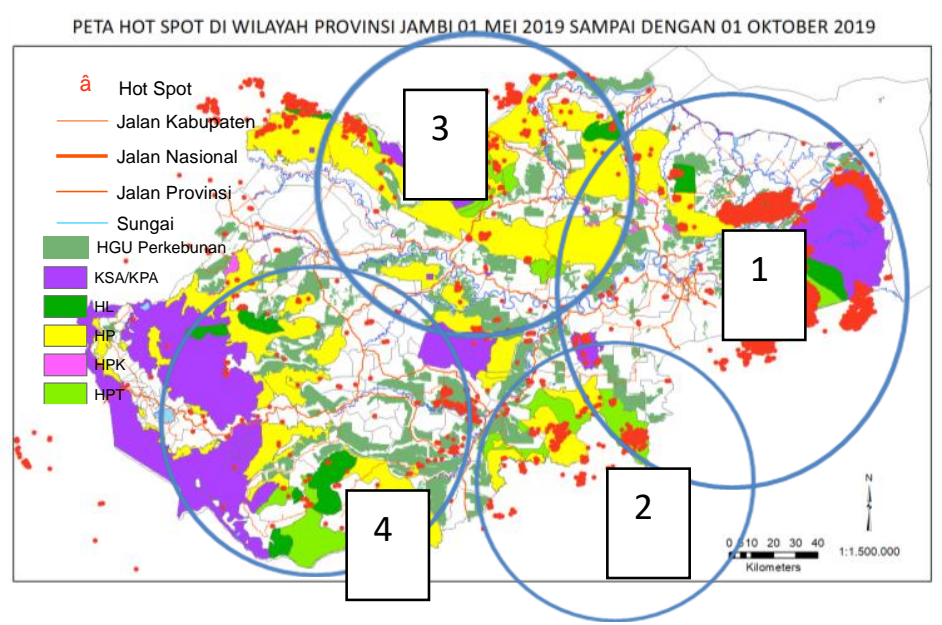

Sebaran Hot Spot dan Prioritas Gakkum LH

1. Kab. Muaro Jambi (10 Perusahaan) dan Tanjab Timur (3 Perusahaan)

2. Kab. Btg. Hari dan Sarolangun (9 Perusahaan)

3. Kab. Tebo dan Bungo (7 Perusahaan)

4. Kab. Tanjab Barat (2 Perusahaan) ${ }^{12}$

Dari peta hotspot di wilayah Provinsi Jambi dari bulan mei 2019 sampai dengan bulan oktober 2019 adalah Total Luas terbakar \pm 41.294 Ha.

Menurut Direktur Walhi Jambi, Rudiansyah di Jambi mengatakan, hasil kajian dan analisis karhutla 2019 dan data luasan kebakaran yang berhasil dikonsolidasikan maupun yang diolah dengan menggunakan data yang bersumber dari satelit landsat 8 dan Sentinel 2 pada periode 1 Agustus hingga 31 Oktober 2019 termasuk kategori parah. Area terbakar yang diolah dengan metode Normalize Burn Ratio dan Hotspot overlay menunjukkan angka luasan kebakaran 165.186,58 hektare dengan komposisi di wilayah gambut 114.900,2 hektare dan non gambut 50.286.38 hektare. ${ }^{13}$

${ }^{12}$ https://firms.modaps.eosdis.nasa.gov/data/download/DL_FIRE_M6_77110.zip

${ }^{13}$ Diunduh dari metrojambi.com tanggal 27 September 2020 
Dari data Dinas Lingkungan Hidup Provinsi Jambi Verifikasi Lapangan Karhutla Muara Jambi dapat dilihat:

\begin{tabular}{|c|c|c|c|c|c|c|c|c|c|c|}
\hline No & NAMA PERUSAHAAN & BIDANG USAHA & $\begin{array}{l}\text { PENERBIT IZIN } \\
\text { LINGKUNGAN }\end{array}$ & $\begin{array}{c}\text { TANGGAL } \\
\text { PEMASANGANGAN } \\
\text { PLANK PPLH/PPNS }\end{array}$ & $\begin{array}{c}\text { TANGGAL } \\
\text { PENGAWASAN } \\
\text { LAPANGAN/VERIFIKASI } \\
\text { LAPANGAN }\end{array}$ & $\begin{array}{l}\text { LEADER PENERAPAN SANKSI } \\
\text { ADMINISTRATIF }\end{array}$ & $\begin{array}{c}\text { LUAS KAJIAN } \\
\text { DOKUMEN } \\
\text { LINGKUNGAN/IZIN } \\
\text { LOKASI* }\end{array}$ & $\begin{array}{l}\text { Luas } \\
\text { Terbakar } \\
\text { (ha) }\end{array}$ & $\begin{array}{c}\text { Persentase } \\
\text { Terbakar } \\
(\%)\end{array}$ & $\begin{array}{c}\text { TINDAK LANJUT } \\
\text { PENERAPAN SANKSI } \\
\text { ADMINISTRATIF }\end{array}$ \\
\hline 1 & PT. PUTRA DUTA INDAHWOOD & IUPHHK-HA & Bupati Muaro Jambi & 24-Sep-19 & $30-0 k t-19$ & $\begin{array}{c}\text { Papan Plank GAKKUM WILAYAH } \\
\text { SUMATERA, Pengawasan Oleh } \\
\text { Gakkum dan DLH Prov }\end{array}$ & 34.730 & 16.327 & $47,01 \%$ & MENTERI KLHK \\
\hline 2 & PT. MEGA ANUGRAH SAWIT & KEBUN SAWIT & Bupati Muaro Jambi & 10-Sep-19 & 10-Sep-19 & PPSA Bersama DLH Prov & 1.500 & 1.387 & $92,46 \%$ & MENTERI KLHK/BUPATI \\
\hline 3 & PT. BARA EKA PRIMA & KEBUN SAWIT & Bupati Muaro Jambi & 24-Sep-19 & 24-Sep-19 & PPSA Bersama DLH Prov & 4.575 & 2.005 & $43,83 \%$ & MENTERI KLHK/BUPATI \\
\hline 4 & PT. SAWIT MAS PLANTATION & KEBUN SAWIT & Bupati Muaro Jambi & & 23-0kt-19 & DLH Prov Jambi & 2.780 & 800 & $28,78 \%$ & BUPATI MUARO JAMBI \\
\hline 5 & PT. WANASEPONJEN INDAH & KEBUN SAWIT & Bupati Muaro Jambi & & 21-0kt-19 & DLH Prov Jambi & 1.711 & 32 & $1,87 \%$ & BUPATI MUARO JAMBI \\
\hline 6 & PT. PESONA BELANTARA PERSADA & IUPHHK-HA & Gubernur Jambi & 24-Sep-19 & $30-0 k t-19$ & $\begin{array}{c}\text { Papan Plank GAKKUM WILAYAH } \\
\text { SUMATERA, Pengawasan Oleh } \\
\text { Gakkum dan DLH Prov }\end{array}$ & 21.135 & 18.212 & $86,17 \%$ & $\begin{array}{c}\text { MENTERI } \\
\text { KLHK/GUBERNUR } \\
\text { JAMBI }\end{array}$ \\
\hline 7 & PT. PURI HIJAU LESTARI & KEBUN SAWIT & Gubernur Jambi & & $10-0 k t-19$ & DLH Prov Jambi & 10.209 & 53 & $0,52 \%$ & GUBERNUR JAMBI \\
\hline 8 & $\begin{array}{l}\text { PT. RICKY KURNIAWAN } \\
\text { KERTAPERSADA }\end{array}$ & KEBUN SAWIT & Gubernur Jambi & $\begin{array}{c}25 / 09 / 2019 \text { dan } \\
27 / 09 / 2019\end{array}$ & $\begin{array}{c}25 / 09 / 2019 \text { dan } \\
27 / 09 / 2019 \\
\end{array}$ & PPSA Bersama DLH Prov & 6.697 & 1.200 & $17,92 \%$ & $\begin{array}{c}\text { MENTERI } \\
\text { KLHK/GUBERNUR }\end{array}$ \\
\hline 9 & PT. BATANGHARI SAWIT SEJAHTERA & KEBUN SAWIT & Gubernur Jambi & & $15-0 \mathrm{kt}-19$ & DLH Prov Jambi & 18.000 & 2 & $0,01 \%$ & GUBERNUR JAMBI \\
\hline 10 & PT. WIRAKARYA SAKTI (DISTRIK VII) & IUPHHK-HTI & Gubernur Jambi & & 06-0kt-19 & DLH Prov Jambi & 290.378 & 334 & $0,12 \%$ & $\begin{array}{c}\text { MENTERI } \\
\text { KLHK/GUBERNUR }\end{array}$ \\
\hline 11 & PT. BUKIT BINTANG SAWIT & KEBUN SAWIT & Bupati Muaro Jambi & & 21-0kt-19 & DLH Prov Jambi & 290.378 & 8 & $0,00 \%$ & BUPATI MUARO JAMBI \\
\hline & & & & & & & $391.713,81$ & $40.351,67$ & $10,30 \%$ & \\
\hline
\end{tabular}

Sumber Data: Bidang Penaatan LH Dinas Lingkungan Hidup Provinsi Jambi 2019.

Berdasarkan Data dari Bidang Penataan LIngkungan Hidup Dinas Lingkungan Hidup Provinsi jambi Perusahaan-Perusahaan yang melakukan kebakaran hutan dan lahan di Kabupaten Muaro Jambi Tahun 2019 Adalah:

Evi Sahrul, Kepala Seksi Kepala Seksi Penegakan Hukum Lingkungan Dinas Lingkungan Hidup Provinsi Jambi menyebutkan:

"Penerapan sanksi terhadap pelaku pembakaran lahan perkebunan sudah berjalan yaitu berupa sanksi pidana, sudah ada yang ditangkap dan sudah ada yang dipenjara. Akibat dari penerapan sanksi tersebut, memberikan efek jera kepada pelaku pembakaran hutan dan lahan sehingga dapat menekan angka kebakaran lahan setiap tahunnya. Untuk Kabupaten Muaro Jambi pelaku kebakaran hutan dan lahan yang dilakukan oleh beberapa perusahaan sampai saat ini masih dalam proses penyidikan di Polda Jambi". ${ }^{14}$

Dari pernyataan tersebut dapat dilihat bahwa Penegakan hukum dari masalah kebakaran lahan perkebunan lebih banyak diterapkan sanksi pidana. Seiring dengan Junaidi, Izhar, Kepala Seksi Perlindungan Dinas Perkebunan dan Peternakan Kabupaten Muaro Jambi, menyebutkan:

14 Wawancara dengan Evi Sahrul, Kepala Seksi Kepala Seksi Penegakan Hukum Lingkungan Dinas Lingkungan Hidup Provinsi Jambi 
“Untuk penerapan sanksi administrasi terhadap pembakaran lahan perkebunan baik badan hukum maupun masyarakat belum pernah diterapkan oleh pemerintah Kabupaten Muaro Jambi, karena terhambat masalah kewenangan. Kewenangan untuk menerapkan sanksi administrasi merupakan kewenangan Pemerintah Provinsi dan kami hanya berwenang di dalam kawasan hutan dan diluar kawasan hutan bukan termasuk kewenangan kami"'.15

Upaya penegakan sanksi administrasi oleh pemerintah secara konsisten sesuai dengan kewenangan yang ada akan berdampak bagi penegakan hukum terutama dalam rangka menjaga kelestarian fungsi lingkungan hidup. Sehubungan dengan hal ini maka penegakan sanksi administrasi merupakan garda terdepan dalam penegakan hukum lingkungan (primum remedium). Jika sanksi administrasi dinilai tidak efektif barulah dipergunakan sarana sanksi pidana sebagai senjata pamungkas (ultimum remedium).

\section{Bentuk Pertanggungjawaban terhadap Pembakaran Hutan dan Lahan di Kabupaten Muaro Jambi}

Sektor kehutanan juga menyerap banyak tenaga kerja dan mampu mendorong terbentuknya sentra ekonomi dan membuka keterisolasian di beberapa daerah terpencil. Namun, bersamaan dengan itu maka dampak negatif atas pengelolaan hutan yang eksploitatif dan tidak berpihak pada kepentingan rakyat, pada akhirnya menyisakan permasalahan di antaranya kerusakan hutan. ${ }^{16}$

Kebakaran hutan terjadi karena beberapa faktor, yakni karena manusia dan faktor alam itu sendiri. Faktor alam biasa terjadi pada musim kemarau ketika cuaca sangat panas. Namun, sebab utama dari kebakaran adalah pembukaan lahan yang meliputi:

1. Pembakaran lahan yang tidak terkendali yang dilakukan masyarakat maupun perusahaan.

2. Penggunaan lahan yang menjadikan lahan rawan kebakaran, misalnya di lahan bekas HPH dan di daerah yang beralang-alang.

3. Konflik antara pihak pemerintah, perusahaan dan masyarakat karena status lahan sengketa perusahaan-perusahaan kelapa sawit kemudian menyewa tenaga kerja dari luar untuk bekerja dan membakar lahan masyarakat lokal yang lahannya ingin diambil alih oleh perusahaan, untuk mengusir masyarakat.

4. Tingkat pendapatan masyarakat yang relatif rendah, sehingga terpaksa memilih alternatif yang mudah, murah, dan cepat untuk pembukaan lahan.

Muaro Jambi

${ }^{15}$ Wawancara dengan Izhar, Kepala Seksi Perlindungan Dinas Perkebunan dan Peternakan Kabupaten

16 Nurhasan Ismail, Penegakan Hukum Kebakaran Hutan dan Lahan, Makalah disampaikan pada tanggal 7 Desember 2015 dalam Seminar Penegakan Hukum Perspektif Kebakaran Hutan. 
5. Sambaran petir pada hutan yang kering karena musim kemarau yang panjang.

6. Kecerobohan manusia antara lain membuang puntung rokok secara sembarangan dan lupa mematikan api di perkemahan.

7. Aktivis vulkanis seperti terkena aliran lahar atau awan panas dari letusan gunung berapi.

8. Kebakaran di bawah tanah/ground fire pada daerah tanah gambut yang dapat menyulut kebakaran di atas tanah pada saat musim kemarau. ${ }^{17}$

Untuk menentukan siapa-siapa yang bertanggungjawab di antara pengurus suatu badan hukum yang harus memikul beban pertanggungjawaban pidana tersebut, harus ditelusuri segi dokumen AMDAL, izin (lisensi) dan pembagian tugas pekerjaan dalam jabatan yang terdapat pada badan hukum (korporasi) yang bersangkutan. Penelusuran dan dokumen-dokumen tersebut akan menghasilkan data, informasi dan fakta dampak negatif yang ditimbulkan oleh kegiatan usaha yang bersangkutan dan sejauhmana pemantauan dan pengendalian yang telah dilakukan terhadap dampak tersebut. Dari dokumen-dokumen tersebut dapat diketahui pula, bagaimana hak dan kewajiban pengurus-pengurus perusahaan tersebut, untuk memantau, mencegah dan mengendalikan dampak negatif kegiatan perusahaan. Sehingga dari penelusuran itu, akan nyata pula apakah pencemaran dan/atau perusakan lingkungan tersebut terjadi karena kesengajaan atau karena kelalaian. $^{18}$

Prinsip tanggung jawab mutlak mutlak (Strict Liability) merupakan gagasan yang disampaikan dalam UU No. 32 Tahun 2009 tentang Perlindungan dan Pengelolaaan Lingkungan Hidup Pasal 88 "Setiap orang yang tindakannya, usahanya, dan/atau kegiatannya menggunakan B3, menghasilkan dan/atau mengelola limbah B3, dan/atau yang menimbulkan ancaman serius terhadap lingkungan hidup bertanggung jawab mutlak atas kerugian yang terjadi tanpa perlu pembuktian unsur kesalahan". Didalam penjelasan Pasal 88 "Yang dimaksud dengan "bertanggung jawab mutlak" atau strict liability adalah unsur kesalahan tidak perlu dibuktikan oleh pihak penggugat sebagai dasar pembayaran ganti rugi". Ketentuan ayat ini merupakan lex specialis dalam gugatan tentang perbuatan melanggar hukum pada umumnya.Dalam lapangan Hukum Perdata, asas tanggung jawab mutlak (Strict Liability) merupakan salah satu jenis pertanggungjawaban Perdata (Civil Liability). Pertanggungjawaban perdata dalam konteks penegakan hukum lingkungan merupakan instrumen hukum perdata untuk mendapatkan ganti kerugian dan biaya pemulihan lingkungan akibat pencemaran dan atau perusakan lingkungan. Pertanggungjawaban perdata tersebut mengenal 2 (dua) jenis pertanggungjawaban yaitu pertanggungjawaban yang mensyaratkan

17 Nuzul Quraini Madya, Pengaturan Pertanggungjawaban Korporasi dalam tindak pisana lingkungan hidup, Jurnal Hukum dan Peradilan, Volume 7 Nomor 3, November 2018 : 483 - 502, halm. 487.

${ }^{18}$ Harun M. Husein, Lingkungan Hidup Masalah, Pengelolaan dan Penegakan Hukumnya, (Jakarta: Bumi Aksara, 1993), hlm 180-181 
adanya pembuktian terhadap unsur kesalahan yang menimbulkan kerugian (fault based liability); dan pertanggungjawaban mutlak/ketat (Strict Liability), suatu pertanggungjawaban tanpa harus dibuktikan adanya unsur kesalahan, dimana pertanggungjawaban dan ganti kerugian seketika muncul setelah perbuatan dilakukan.

Namun keberadaan asas tanggung jawab mutlak tersebut dalam Pasal 88 UU No. 32 tahun 2009 ternyata belum dapat dilaksanakan secara maksimal, karena berseberangan dengan sistem dalam pembuktian dalam proses hukum acara perdata yang telah ditentukan dalam Pasal 1865 BW jo $163 \mathrm{HIR} / 263 \mathrm{RBg}$ bahwa barangsiapa yang mendalilkan atas suatu hak, maka ia wajib membuktikan dalilnya tersebut, yang berarti bahwa penggugatlah yang diwajibkan untuk membuktikan telah terjadi pencemaran lingkungan yang mengakibatkan kerugian, serta harus membuktikan adanya unsur kesalahan si pelaku dalam pencemaran dan perusakan lingkungan tersebut. Dan apabila unsur kesalahan tersebut tidak dapat dibuktikan maka tidak ada ganti kerugian.

Selain dari persoalan beban pembuktian tersebut di atas, penerapan asas strict liability juga belum dapat dimaksimalkan dikarenakan ketentuan dalam Pasal 88 UU No. 32 tahun 2009 sendiri juga telah membatasi dalam hal tertentu dapat digunakannnya pertanggungjawaban secara mutlak (strict liability), yaitu hanya terhadap pencemaran lingkungan yang mengandung limbah B3 (Bahan Berbahaya dan Beracun). Padahal pencemaran dan perusakan lingkungan sekecil apapun pasti akan berdampak pada berkurangnya kualitas lingkungan sebagai penunjang kehidupan manusia yang akhirnya pasti juga akan berdampak pada keberlangsungan hidup manusia sendiri. Misalnya penebangan beberapa batang pohon di hutan tanpa ijin, kegiatan penebangan pohon tersebut tidak menghasilkan limbah B3, akan tetapi apabila dibiarkan terus menerus maka akan terjadi banjir, tanah longsor yang akan berdampak langsung pada manusia hingga bahkan dapat menyebabkan kematian banyak orang. Yang harus dilakukan oleh Perusahaan untuk menghindari tanggungjawab adalah:

1. Memastikan bahwa semua kewajiban administratif telah terpenuhi untuk mengurangi kemungkinan dilakukannya penuntutan pidana

2. Memastikan bahwa terdapat tindakan pencegahan (due care) untuk menghindari gugatan berdasarkan perbuatan melawan hukum untuk membuktikan bahwa tidak terdapat kelalaian maupun kesengajaan dalam tindakan bersangkutan (tidak berlaku untuk gugatan strict liability)

3. Dalam hal sudah terjadi pencemaran, melibatkan konsultan lingkungan hidup dan konsultan hukum untuk memperoleh nasihat yang tepat untuk pengambilan strategi ke depannya

4. Melakukan mitigasi terhadap akibat yang ditimbulkan terhadap lingkungan dan dengan itikad baik bekerjasama dengan masyarakat sekitar dan pihak 
pemerintah untuk meningkatkan kemungkinan diringankannya pidana yang dijatuhkan

5. Berusaha menandatangani perjanjian penyelesaian dengan masyarakat sekitar yang mendapatkan kerugian.

6. Dalam hal sudah dimulainya langkah penyidikan, melibatkan ahli hukum lingkungan hidup untuk membuktikan bahwa perusahaan tidak memenuhi unsur-unsur tindak pidana.

7. Apabila sudah ditetapkan sebagai tersangka, mencoba memperoleh SP3 atau melakukan upaya hukum pra-peradilan

Bahwa dalam konteks strict liability, cara satu-satunya adalah membuktikan bahwa tindakan disebabkan sesuatu yang berada di luar kendali manusia (act of god/force majeur).Ketentuan sanksi administrasi ini tidak terdapat dalam UULH, karena pada umumnya sanksi administrasi terkait dengan sistem perizinan. Seorang yang tidak melaksanakan ketentuan sebagaimana tercantum dalam izin yang diberikan dikenakan sanksi administrasi yang diberikan oleh instansi yang berwenang memberi izin. Dalam UUPLH diadakan ketentuan dengan sanksi administrasi, sehingga diperoleh ketentuan yang lebih jelas, yang dapat diterapkan oleh instansi yang terkait Pasal 25 UUPLH menyatakan: Gubernur/Kepala Daerah Tingkat I berwenang melakukan paksaan pemerintahan terhadap penanggungjawab usaha dan/atau kegiatan untuk mencegah dan mengakhiri terjadinya pelanggaran, serta menanggulangi akibat yang ditimbulkan oleh suatu pelanggaran, melakukan tindakan penyelamatan, penanggulangan, dan/atau pemulihan atas beban biaya penanggungjawab usaha dan/atau kegiatan, kecuali ditentukan lain berdasarkan undang-undang.Paksaan pemerintahan sebagaimana dimaksud pada ayat (1) dan ayat (2), didahului dengan surat perintah dari pejabat yang berwenang. Tindakan penyelamatan, penanggulangan dan/atau pemulihan sebagaimana dimaksud pada ayat (1) dapat diganti dengan bayaran sejumlah uang tertentu. Penegakan sanksi administrasi merupakan hal terdepan dalam penegakan hukum lingkungan. Jika sanksi administrasi dinilai tidak efektif, barulan dipergunakan sarana sanksi pidana sebagai senjata pamungkas. Ini berarti bahwa kegiatan penegakan hukum pidana terhadap suatu tindak pidana lingkungan hidup baru dapat dimulai apabila : Aparat yang berwenang telah menjatuhkan sanksi administrasi dan telah menindak pelanggar dengan menjatuhkan suatu sanksi administrasi tersebut, namun ternyata tidak mampu menghentikan pelanggaran yang terjadi, atau antara perusahaan yang melakukan pelanggaran dengan pihak masyarakat yang menjadi korban akibat terjadi pelanggaran, sudah diupayakan penyelesaian sengketa melalui mekanisme altenatif di luar pengadilan dalam bentuk musyawarah/perdamaian /negoisasi/mediasi, namun upaya yang dilakukan menemui jalan buntu, dan atau litigasi melalui pengadilan pedata, namun upaya tersebut juga tidak efektif, baru dapat digunakan instrumen penegakan hukum pidana lingkungan hidup. Dan 
konsep Strict Liability atau tanggung jawab mutlak harus diwaspadai pelaku usaha berkaitan aspek lingkungan. Korporasi dapat dihukum mengganti rugi hingga ratusan milyar, cukup dengan terbukti mengakibatkan ancaman serius bagi lingkungan dan menimbulkan kerugian bagi penggugat, yang tidak perlu ada unsur kesalahan.

\section{KESIMPULAN}

Kebakaran hutan dan lahan gambut di Muaro Jambi terjadi sejak Agustus-Oktober 2019 diperkirakan sudah mencapai \pm 40.351 hektare. Kebakaran hutan dan lahan gambut tersebut terjadi di areal HPH dan juga perusahaan perkebunan kelapa sawit. Pemerintah selaku pejabat yang berwenang dalam menangani masalah hal ini harus dapat menjatuhkan sanksi yang tegas yaitu berupa penjatuhan sanksi administrasi kepada pelaku pembakaran lahan perkebunan. Adapun sanksi administrasi tersebut adalah:

1. Paksaan pemerintah (bestuursdwang);

2. Penarikan kembali keputusan (ketetapan) yang menguntungkan;

3. Uang paksa (dwangsom); dan

4. Denda administratif.

Prinsip tanggung jawab mutlak mutlak (Strict Liability) merupakan gagasan yang disampaikan dalam UU No. 32 Tahun 2009 tentang Perlindungan dan Pengelolaaan Lingkungan Hidup Pasal 88 "Setiap orang yang tindakannya, usahanya, dan/atau kegiatannya menggunakan B3, menghasilkan dan/atau mengelola limbah B3, dan/atau yang menimbulkan ancaman serius terhadap lingkungan hidup bertanggung jawab mutlak atas kerugian yang terjadi tanpa perlu pembuktian unsur kesalahan". Didalam penjelasan Pasal 88 "Yang dimaksud dengan "bertanggung jawab mutlak" atau strict liability adalah unsur kesalahan tidak perlu dibuktikan oleh pihak penggugat sebagai dasar pembayaran ganti rugi". Ketentuan ayat ini merupakan lex specialis dalam gugatan tentang perbuatan melanggar hukum pada umumnya. Dan konsep Strict Liability atau tanggung jawab mutlak harus diwaspadai pelaku usaha berkaitan aspek lingkungan. Korporasi dapat dihukum mengganti rugi hingga ratusan milyar, cukup dengan terbukti mengakibatkan ancaman serius bagi lingkungan dan menimbulkan kerugian bagi penggugat, yang tidak perlu ada unsur kesalahan.

\section{Saran}

1. Diharapkan Pemerintah Provinsi sesuai dengan kewenangannya berdasarkan UU 23 Tahun 2004 tentang Pemerintahan Daerah dan pengaturan yang lebih jelas lagi sesuai Undang-Undang 32 Tahun 2009 tentang UUPPLH agar dapat menerapkan sanksi administrasi yang tegas terhadap pelaku pembakaran lahan perkebunan. Serta peran Pemerintah Kabupaten Muaro Jambi dapat 
memperkuat kelembagaan dan peraturan perundang-undangan yang mendukung pembukaan lahan tanpa bakar (zero burning), pencegahan kebakaran hutan dan lahan, serta pencemaran kabut asap sehingga langkah hukum yang diharapkan dapat menjangkau para pelaku pembakaran lahan dan hutan yang selama ini memberikan dampak buruk secara sosial dan ekonomi kepada negara.

2. Diharapkan perlunya penyuluhan hukum terutama mengenai hukum kehutanan kepada masyarakat sehingga masyarakat mengetahui peraturan yang mengatur perlindungan hutan akibat kebakaran hutan dan lahan oleh badan hukum perdata.

\section{DAFTAR PUSTAKA}

\section{Buku}

Adrian Sutedi, Hukum Perizinan dalam sektor Pelayanan Publik, Sinar Grafika, Jakarta, 2010.

Bahder Johan Nasution, Metode penelitian Ilmu Hukum, CV. Mandar Maju, Bandung, 2008.

Harun M. Husein, Lingkungan Hidup Masalah, Pengelolaan dan Penegakan Hukumnya, Jakarta: Bumi Aksara, 1993

Harjasoemantri, Koesnadi.. Strict Liability (Tanggung Jawab Mutlak). Paper presented at the Lokakarya Legal Standing \& Class Action, Hotel Kartika Chandra, Jakarta, 1998

Helmi, Hukum Perizinan Lingkungan Hidup, Sinar Grafika, Jakarta, 2012.

Muladi dan Dwidja Priyatno, Pertanggungjawaban Pidana Korporasi, Kencana, 2010.

Philipus M. Hadjon, et. al, Pengantar Hukum Administrasi Indonesia, Gadjah Mada University Press, Yogyakarta, 1993.

Rachmat Setiawan, Tinjauan Elementer Perbuatan Melawan Hukum, Alumni, Bandung. 1982.

Ridwan HR, Hukum Administrasi Negara, Cetakan ke-11, Rajawali Pers, Jakarta, 2014.

Salim, Dasar-Dasar Hukum Kehutanan, Cetakan Kelima, Sinar Grafika, Jakarta, 2013.

Soerjono Soekanto, Faktor-Faktor yang mempengaruhi Penegakan Hukum, Cetakan ke14, Rajawali Press, Jakarta, 2014.

, Penegakan Hukum, Bina Cipta, jakarta, 1983.

Takdir Rahmadi, Hukum lingkungan Indonesia, Raja Grafindo Persada, jakarta, 2012.

\section{Jurnal/Karya Ilmiah}

Erdiansyah, Implementasi Pertanggungjawaban Pidana Korporasi Pembakaran Hutan Dan Lahan di Provinsi Riau, VOLUME 4 NO. 3 September 2014-Januari 2015 Jurnal Ilmu Hukum. 
Nurhasan Ismail, Penegakan Hukum Kebakaran Hutan dan Lahan, Makalah disampaikan pada tanggal 7 Desember 2015 dalam Seminar Penegakan Hukum Perspektif Kebakaran Hutan

Nuzul Quraini Madya, Pengaturan Pertanggungjawaban Korporasi dalam tindak pisana lingkungan hidup, Jurnal Hukum dan Peradilan, Volume 7 Nomor 3, November $2018: 483-502$

Inosentius Samsul, "Instrumen Hukum Penanggulangan Kebakaran Hutan, Lahan, Dan Polusi Asap", Info Singkat, Vol. VII, No. 17/I/P3DI/September/2015.

Kementerian Pertanian Direktorat Jenderal Perkebunan, "Pengawasan dan upaya pengendalian perizinan usaha perkebunan", Jakarta, 2014.

\section{Peraturan Perundang-undangan}

Republik Indonesia, Undang-Undang Dasar Negara Republik Indonesia Tahun 1945. Undang-undang Nomor 41 Tahun 1999 Tentang Kehutanan

Undang-undang Nomor 32 Tahun 2009 Tentang Perlindungan dan Pengelolaan Ligkungan Hidup

Undang-undang Nomor 23 Tahun 2014 Tentang Pemerintah Daerah

Undang-Undang Nomor 39 Tahun 2014 Tentang Perkebunan

Peraturan Menteri Kehutanan Nomor: P. 12/Menhut-Ii/2009 Tentang Pengendalian Kebakaran Hutan

\section{Internet}

http://trishadennis.blogspot.co.id/2012/10/kebakaran-

hutan.htmlhttp://andre4088.blogspot.co.id/2012/08/tipe-tipe-kebakaran-shutan.html 